\title{
Rola Zintegrowanego Programu Operacyjnego Rozwoju Regionalnego i Regionalnych Programów Operacyjnych w realizacji procesów rewitalizacji
}

Przedsiębiorczość w warunkach integracji europejskiej jest jednym z kluczowych czynników sukcesu, zarówno w kontekście pojedynczych osób, przedsiębiorstw czy miast, jak i jednostek samorządów terytorialnych oraz państw. W przypadku osób postawa przedsiębiorcza rozumiana jest jako zespół cech osobowych, takich jak: aktywność, zapał do pracy, inicjatywa, kreatywność, uczciwość, skłonność do wyważonego ryzyka oraz brania odpowiedzialności za siebie i innych, postępowanie zgodne z zasadami etycznymi, oraz umiejętność stawiania i realizowania postawionych sobie celów poprzez wytyczanie własnej ścieżki kariery zawodowej (Borowiec, Rachwał 2005). W odniesieniu do władz miast przedsiębiorczość można zmierzyć skutecznością w pozyskiwaniu funduszy europejskich oraz umiejętnością ich wykorzystania. W dobie globalizacji oraz silnej konkurencji między miastami zdolność skutecznego zarządzania może przesądzić o wygranej bądź przegranej danej jednostki w „grze o przestrzeń”. Jest to tym ważniejsze, że miasta odgrywają współcześnie podstawową rolę w procesach wzrostu społeczno-gospodarczego, a w konsekwencji - w podnoszeniu konkurencyjności różnej skali układów przestrzennych. W wyniku licznych przemian funkcjonalno-przestrzennych wiele obszarów miejskich zostało zdegradowanych, a inne części miast uzyskały nową rangę. Aby mogła jednak powstać harmonijna przestrzeń miejska, koniecznym stało się podjęcie przedsięwzięć przywracających ład przestrzenny i znaczenie obszarów zmarginalizowanych. Zasadę maksymalizacji wartości miast i ich nieruchomości poprzez kreowanie wysokiej jakości przestrzeni publicznej realizuje się obecnie m.in. poprzez programy rewitalizacji.

Próbę zdefiniowania pojęcia ,rewitalizacja” podjęło wielu autorów artykułów i książek oraz pracowników instytucji publicznych pracujących nad ustawami dotyczącymi tego problemu. Interesująca jest definicja ekonomiczna rewitalizacji T. Markowskiego. Postrzega on problem rewitalizacji jako proces marginalizacji terenów ,wypadających” z obszarów dynamicznego rozwoju. Nie dotyczy to wyłącznie obszarów peryferyjnych, ale coraz częściej terenów położonych centralnie. Dla Markowskiego zagadnienie rewitalizacji ma przede wszystkim wymiar ekonomiczny, decydujący o powodzeniu lub porażce programów.

Podejmując się polityki rewitalizacyjnej obszarów problemowych w miastach należy zdawać sobie sprawę ze związków, jakie zachodzą pomiędzy generowaniem wartości ziemi, jej ceną, rentą, efektami zewnętrznymi a systemem podatków od wartości nieruchomości. Zrozumienie istoty generowania wartości ziemi jest podstawą koncepcji rewitalizacji obszarów miejskich. Pojawienie się korzyści zewnętrznych na przekształcanym obszarze jest możliwe tylko przy dużej skali tych przekształceń. Przekształcenie tkanki miejskiej jest czasochłonne, a korzyści ujawniają się tylko w długim okresie. Zatem indywidualne, nie skoordynowane w czasie inwestycje nie są w stanie przywrócić możliwości generowania wysokiej renty na 
danym terenie. Wynika to między innymi ze specyficznych fizycznych cech przestrzeni i struktur społecznych miasta, gdyż potencjalne korzyści są niwelowane przez negatywne efekty zewnętrzne (Markowski 1999).

O wymiarach rewitalizacji pisała S. Kaczmarek, rozróżniając wymiar społeczny, przestrzenny, gospodarczy i kulturowy. Zdaniem autorki konieczne jest rozszerzenie takiego zbioru postrzegania zasadniczych cech procesu o wymiar środowiskowy (ekologiczny) i techniczny (techniczno-budowlany). Zasadniczym powodem rewitalizacji jest niewydolność ekonomiczna miasta czy jego fragmentu, co skutkuje jednoczesnym pogorszeniem sytuacji społeczności lokalnej, patologiami, niszczeniem dziedzictwa kulturowego obszaru, dezintegracją funkcji przestrzennej, niszczeniem tkanki budowlanej, degradacją środowiska przyrodniczego. Warto podkreślić, że przyczyną działań rewitalizacyjnych jest zwykle słabość gospodarcza obszaru zurbanizowanego, przedmiotem planowanych działań jest tkanka miejska, a celem całego przedsięwzięcia - ludzie. Rewitalizacja ma wywołać ożywienie fragmentu miasta, dzięki któremu zostanie poprawiona atrakcyjność obszaru, a w konsekwencji tego nastąpi poprawa losu i poziomu bytowania jego mieszkańców (Kaczmarek 2001).

Wielowymiarowe podejście do problemu rewitalizacji prezentuje także K. Skalski: właściwa definicja określa rewitalizację jako kompleksowy program remontów, modernizacji zabudowy i przestrzeni publicznych, rewaloryzacji zabytków na wybranym obszarze, najczęściej dawnej dzielnicy miasta, w powiązaniu z rozwojem gospodarczym i społecznym. Rewitalizacja to połączenie działań technicznych (takich jak np. remonty) z programami ożywienia gospodarczego i działaniem na rzecz rozwiązania problemów społecznych występujących na tych obszarach: bezrobociem, przestępczością, brakiem równowagi demograficznej. Niewłaściwym jest zatem mówienie o rewitalizacji jednego budynku czy rewaloryzacji zabytków (Skalski 2002).

Cele podejmowania wysiłku rewitalizacyjnego są tak różne, jak odmienna jest sytuacja każdego z miast i ośrodków. Można je jednak pogrupować w odniesieniu do zagadnień, jakich procesy rewitalizacji dotyczą:

- urbanistyczno-architektoniczne - związane z remontem i modernizacją lub czasami rewaloryzacją zespołów architektonicznych, w tym mieszkaniowych i poprzemysłowych, a także ze świadomym kształtowaniem krajobrazu kulturowego danego obszaru,

- techniczne - związane z poprawą jakości struktur miejskich, w tym infrastruktury technicznej i drogowej,

- społeczno-ekonomiczne - związane z ożywieniem gospodarczym - działania dotyczące zasobów ludzkich, w tym przeciwdziałanie wykluczeniu społecznemu, zahamowanie rozwoju patologii, zapobieganie zjawisku bezrobocia i bezdomności,

- środowiskowe - związane z polepszeniem stanu środowiska naturalnego (Lorens 2005; Gasidło, Mazur, Opania, Pancewicz 2005).

Dobrze przeprowadzona rewitalizacja to nie tylko odpowiednie rozumienie celów, ale także właściwy wybór terenu objętego działaniem odnowy. Znaczącym czynnikiem jest więc różnorodność obszarów poddawanych rewitalizacji. Każdy z nich charakteryzuje się bowiem odmiennymi problemami, cechami struktury fizycznej i stopniem ich degradacji. W związku z tym obszary te można podzielić na kilka grup. Najczęściej spotykany podział w literaturze przedmiotu to podział ze względu na pełnioną poprzednio funkcję oraz na okres historyczny ukształtowania struktur. W ten sposób wyróżnić można trzy zasadnicze grupy obszarów poddawanych rewitalizacji: mieszkaniowe, śródmiejskie oraz obszary związane z infrastrukturą techniczną i poprzemysłową. Wśród terenów mieszkaniowych można wyróżnić jeszcze podgrupy o genezie XVIII-wiecznej i wcześniejszej, XIX-wiecznej i wczesno-XX-wiecznej, 
międzywojennej i powojennej. Obszary śródmiejskie są centralnie położone, o bardzo zróżnicowanej strukturze urbanistycznej. Ich odnowa polega na poprawie warunków mieszkaniowych, ożywieniu gospodarczym i kreowaniu nowego centrum miasta. Kolejna strefa związana z infrastrukturą techniczną i przemysłową cechuje się całkowitą utratą dotychczasowego znaczenia w strukturze funkcjonalnej miasta. Wyróżnia się tu cztery podstawowe kategorie: obszary poprzemysłowe, poportowe, powojskowe i pokolejowe (Lorens 2005).

\section{Zintegrowany Program Operacyjny Rozwoju Regionalnego}

Osiagnięcie wszystkich celów rewitalizacji wiąże się z posiadaniem odpowiednich środków finansowych. Liczne próby uregulowania spraw odnowy tkanki miejskiej nie nawiązujące do wielopłaszczyznowego i złożonego problemu rewitalizacji utrudniały otrzymanie wsparcia $\mathrm{z}$ budżetu państwa. Nowa perspektywa dla rozwinięcia programów rewitalizacji pojawiła się wraz z przyjęciem przez Radę Ministrów w styczniu 2003 roku Narodowego Planu Rozwoju na lata 2004-2006 oraz przystapieniem Polski do Unii Europejskiej w maju 2004 roku. Fundusze strukturalne dostępne dla państw członkowskich pochodziły z czterech źródeł: Europejskiego Funduszu Rozwoju Regionalnego (EFRR), Europejskiego Funduszu Społecznego (EFS), Europejskiego Funduszu Orientacji i Gwarancji Rolnej (EFOiGR), Finansowego Instrumentu Wspierania Rybołówstwa (FIWR). Jednak przy realizacji działań na rzecz rewitalizacji obszarów miejskich, powojskowych i poprzemysłowych pomocne były przede wszystkim dwa pierwsze źródła. Największa część pomocy z funduszy strukturalnych UE na rozwój regionalny udzielana była beneficjentom w ramach Zintegrowanego Programu Operacyjnego Rozwoju Regionalnego (ZPORR). Na realizację ZPORR w latach 2004-2006 przewidziano łącznie w skali kraju ok. 2,96 mld euro z Europejskiego Funduszu Rozwoju Regionalnego oraz Europejskiego Funduszu Społecznego. Środki te zostały podzielone na alokacje według województw oraz według priorytetów i działań. Od początku realizacji programów operacyjnych do końca sierpnia $2008 \mathrm{r}$. beneficjenci otrzymali z funduszy strukturalnych (przyznanych Polsce na lata 2004-2006) refundacje o wartości blisko 2,74 mld zł, czyli 92,85\% dostępnej alokacji.

Największa alokacja środków przypadła dla województw: mazowieckiego (300 mln euro), śląskiego (280 mln euro) i wielkopolskiego (196 mln euro). Najmniej natomiast dostały województwa: dolnośląskie (37,5 mln euro), opolskie (77 mln euro) i lubuskie $(82,5 \mathrm{mln}$ euro). W przeliczeniu na jednego mieszkańca najwięcej środków przypadło województwom: warmińsko-mazurskiemu (127,5 euro) i świętokrzyskiemu (104 euro), a najmniej - dolnośląskie$\mathrm{mu}$ (13 euro), małopolskiemu (56 euro), mazowieckiemu i wielkopolskiemu (58 euro) (ryc. 1).

Do Zintegrowanego Programu Operacyjnego Rozwoju Regionalnego, jednego z elementów planu, wpisane zostały zadania odnoszące się do problematyki rewitalizacji, zachowania i odbudowy dziedzictwa kulturowego. Jest to częścią Priorytetu 3 - Rozbudowa i modernizacja infrastruktury służącej wzmocnieniu konkurencyjności regionów. Ważnym priorytetem Zintegrowanego Programu „Rozwój lokalny” jest zadanie dotyczące rewitalizacji obszarów zdegradowanych, które zostało dodatkowo podzielone na dwa poddziałania: 3.3.1 - Rewitalizacja obszarów miejskich i 3.3.2 - Rewitalizacja obszarów poprzemysłowych i powojskowych.

W ramach poddziałania 3.3.1 wspierane były projekty, które wynikały ze zintegrowanych programów rewitalizacji społeczno-gospodarczej przestrzennie i funkcjonalnie zdegradowanych dzielnic mieszkaniowych miast w celu:

- tworzenia w zdegradowanych dzielnicach warunków lokalowych i infrastrukturalnych dla rozwoju małej i średniej przedsiębiorczości, 
Ryc. 1. Podział środków w ramach ZPORR

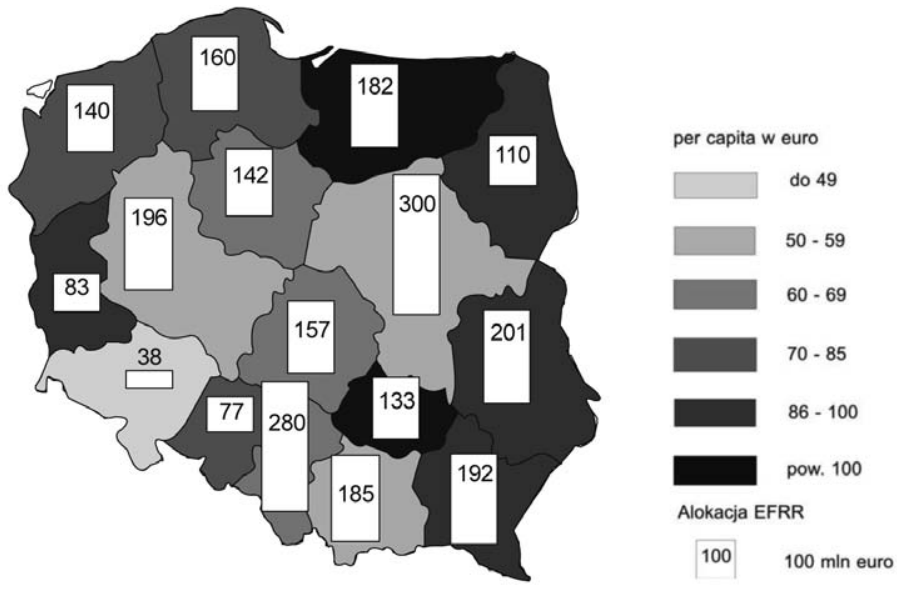

Źródło: opracowanie własne na podstawie ZPORRe zmiany w regionach, Warszawa 2008.

- odpowiedniego wkomponowania w puste przestrzenie nowych obiektów usługowo-handlowo-mieszkaniowych,

- renowacji i modernizacji budynków,

- poprawy funkcjonalności struktury ruchu kołowego i pieszego,

- walki z marginalizacją, patologiami społecznymi,

- poprawy bezpieczeństwa,

- większego utożsamiania się mieszkańców z dzielnicą.

W ramach poddziałania 3.3.2 wspierane były projekty, które wynikały z programów rewitalizacji terenów poprzemysłowych i powojskowych. Celem rewitalizacji obszarów poprzemysłowych była zmiana dotychczasowych funkcji i adaptacja budynków, a w przypadku obszarów powojskowych - przystosowanie terenu pod nowe cele: usługowe, gospodarcze, społeczne, edukacyjne, zdrowotne, kulturalne i turystyczne (Uzupetnienie ZPORR).

Ryc. 2. Średnia wartość projektu przyjętego do realizacji wg województw (w mln euro)

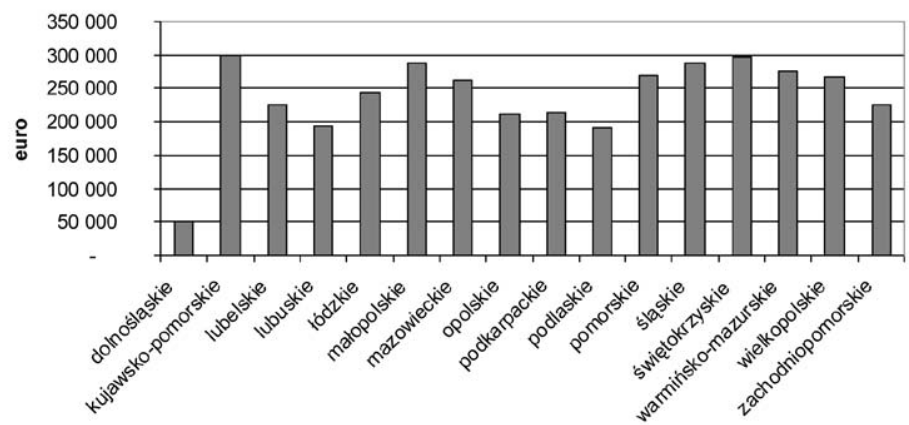

Źródło: opracowanie własne na podstawie ZPORRe zmiany w regionach, Warszawa 2008.

Całkowita wartość środków finansowych z EFRR dla Priorytetu 3 (Rozwój lokalny) na lata 2004-2006 wyniosła 727523283 euro, tj. około 2804751 510,00 zł. Działanie 3.3 (Rewitalizacja obszarów zdegradowanych) zostało dofinansowane kwotą 385970 777,60 zł 
(100 398213 euro), co stanowi 13,8\% środków EFRR przeznaczonych dla Priorytetu 3. Całkowita wartość projektów rewitalizacyjnych wyniosła 659022000 zł.

Wszystkie realizowane projekty można podzielić na różne grupy tematyczne. W ramach podjętych działań 65 projektów dotyczyło przestrzeni publicznych, 62 to renowacje pojedynczych budynków lub ich zespołów, 20 odnosiło się do kompleksów edukacyjnych, kulturalnych, turystycznych, a 31 to przedsięwzięcia kompleksowe (Siemiński, Topczewska 2008).

\section{Regionalne Programy Operacyjne}

Nowy okres programowania to także nowe możliwości wykorzystania funduszy strukturalnych dla wsparcia biznesu, rozwoju miast i przygotowania projektów „dużej” infrastruktury. Działanie 3.3 ZPORR było tylko programem pilotażowym przygotowującym gminy do skorzystania z możliwości pokaźnych dofinansowań z Europejskiego Funduszu Rozwoju Regionalnego. W latach 2007-2013 programami wspomagającymi rewitalizację będą: JESSICA, JASPERS, JEREMIE oraz Programy Operacyjne.

Wśród Programów Operacyjnych ogromne znaczenie mają Regionalne Programy Operacyjne (RPO) opracowywane przez każde z województw. Jako podstawowe dokumenty operacyjne służące realizacji polityki rozwoju regionu zawierają różnego rodzaju priorytety i działania, także związane z rewitalizacją. Na Regionalne Programy Operacyjne przeznaczono 16,5 mld euro, co stanowi 23,8\% całości środków skierowanych na Programy Operacyjne.

Największa alokacja środków przypadła dla województw: mazowieckiego (1,8 mld euro), śląskiego (1,7 mln euro), małopolskiego i wielkopolskiego (po 1,3 mld euro). Najmniej natomiast dostały województwa: opolskie (427 mln euro), lubuskie (439 mln euro) i podlaskie (636 mln euro). W przeliczeniu na jednego mieszkańca najwięcej środków przypadło warmińsko-mazurskiemu (727 euro) i świętokrzyskiemu (568,5 euro), a najmniej - mazowieckiemu (353 euro), śląskiemu (368 euro) i wielkopolskiemu (376 euro) (ryc. 3).

W podziale na poszczególne działania najwięcej przeznaczono na transport oraz badania i rozwój, a na rewitalizację przewidziano 5,6\% z 16,5 mln euro, co daje sumę 944 mln euro (ryc. 4).

\section{Ryc. 3. Podział środków w ramach RPO}

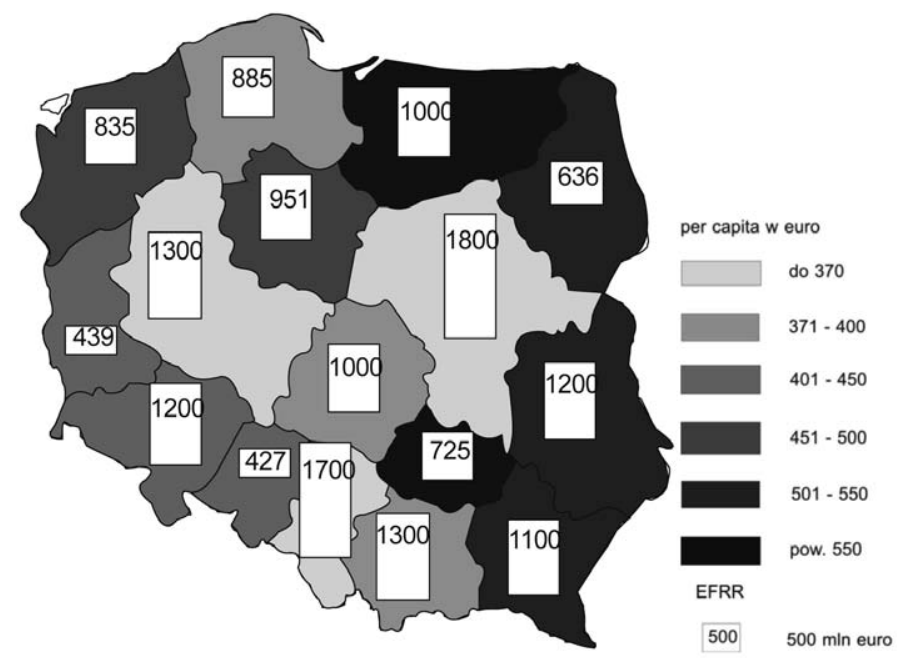

Źródło: opracowanie własne na podstawie RPO. 
Ryc. 4. Środki unijne przeznaczone na realizację poszczególnych zadań w ramach RPO

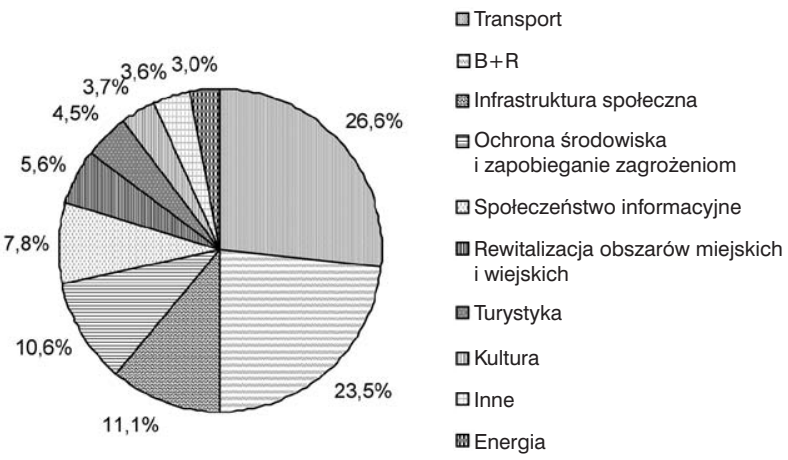

Źródło: opracowanie własne na podstawie Uszczegółowień RPO.

Tab. 1. Środki na rewitalizację w Regionalnych Programach Operacyjnych

\begin{tabular}{|c|c|c|c|}
\hline Województwo & Priorytet/Dzialanie & $\begin{array}{c}\text { Alokacja } \\
\text { finansowa } \\
\text { ogólem } \\
\text { (w euro) }\end{array}$ & $\begin{array}{c}\text { Wkład } \\
\text { ze środków } \\
\text { unijnych } \\
\text { (w euro) }\end{array}$ \\
\hline \multirow{3}{*}{ dolnośląskie } & \multicolumn{3}{|c|}{ Priorytet IX - Odnowa zdegradowanych obszarów miejskich na terenie Dolnego Śląska } \\
\hline & $\begin{array}{l}\text { 9.1. Odnowa zdegradowanych obszarów miejskich w miastach } \\
\text { powyżej } 10 \text { tys. mieszkańców }\end{array}$ & 137400558 & 96180391 \\
\hline & $\begin{array}{l}\text { 9.2. Wsparcie dla przedsięwzięć w zakresie mieszkalnictwa } \\
\text { w miastach poniżej } 10 \text { tys. mieszkańców }\end{array}$ & 15266713 & 10686699 \\
\hline \multirow{3}{*}{$\begin{array}{l}\text { kujawsko- } \\
\text {-pomorskie }\end{array}$} & \multicolumn{3}{|c|}{ Priorytet VII - Wspieranie przemian w miastach i w obszarach wymagających odnowy } \\
\hline & 7.1. Rewitalizacja zdegradowanych dzielnic miejskich & 86932938 & 70374283 \\
\hline & $\begin{array}{l}\text { 7.2. Adaptacja do nowych funkcji społeczno-gospodarczych } \\
\text { terenów poprzemysłowych i powojskowych }\end{array}$ & 18796310 & 15216061 \\
\hline \multirow{2}{*}{ lubelskie } & \multicolumn{3}{|l|}{ Priorytet III - Atrakcyjność terenów miejskich i tereny inwestycyjne } \\
\hline & 3.2. Rewitalizacja zdegradowanych obszarów miejskich & 84761592 & 50893724 \\
\hline \multirow[b]{2}{*}{ lubuskie } & \multicolumn{3}{|l|}{ Priorytet IV - Rozwój i modernizacja infrastruktury społecznej } \\
\hline & $\begin{array}{l}\text { 4.3. Rewitalizacja zdegradowanych obszarów miejskich } \\
\text { i wiejskich }\end{array}$ & 31428798 & 25618911 \\
\hline \multirow{3}{*}{ łódzkie } & \multicolumn{3}{|l|}{ Priorytet VI - Odnowa obszarów miejskich } \\
\hline & 6.1. Rewitalizacja obszarów problemowych & 106640880 & 90644748 \\
\hline & 6.2. Renowacja substancji mieszkaniowej & 11756874 & 9993343 \\
\hline \multirow[b]{2}{*}{ małopolskie } & \multicolumn{3}{|l|}{ Priorytet VI - Spójność wewnątrzregionalna } \\
\hline & $\begin{array}{l}\text { 6.1. Rozwój miast, projekty realizowane wyłącznie w ramach } \\
\text { programów rewitalizacji }\end{array}$ & 95123798 & 77002477 \\
\hline \multirow{2}{*}{ mazowieckie } & \multicolumn{3}{|l|}{ Priorytet $\mathrm{V}$ - Wzmocnienie roli miast $\mathrm{w}$ rozwoju regionu } \\
\hline & 5.2. Rewitalizacja & 105580400 & 89743340 \\
\hline \multirow{3}{*}{ opolskie } & \multicolumn{3}{|l|}{ Priorytet VI - Aktywizacja obszarów miejskich i zdegradowanych } \\
\hline & 6.1. Rewitalizacja obszarów miejskich & 38593790 & 20502951 \\
\hline & 6.2. Zagospodarowanie terenów zdegradowanych & 26487165 & 13668634 \\
\hline
\end{tabular}




\begin{tabular}{|c|c|c|c|}
\hline \multirow{4}{*}{ podkarpackie } & \multicolumn{3}{|l|}{ Priorytet VII - Spójność wewnątrzregionalna } \\
\hline & 7.1. Rewitalizacja miast & 47541114 & 36930004 \\
\hline & 7.2. Rewitalizacja obszarów zdegradowanych & 31248465 & 25566926 \\
\hline & 7.3. Aktywizacja obszarów zdegradowanych gospodarczo & 20637355 & 17044617 \\
\hline \multirow{2}{*}{ podlaskie } & \multicolumn{3}{|c|}{ Priorytet I - Wzrost innowacyjności i wspieranie przedsiębiorczości w regionie } \\
\hline & 1.1. Tworzenie warunków dla rozwoju innowacyjności & 43920294 & 29986294 \\
\hline \multirow{4}{*}{ pomorskie } & \multicolumn{3}{|l|}{ Priorytet III - Funkcje miejskie i metropolitalne } \\
\hline & \multicolumn{3}{|l|}{ 3.2. Wzrost atrakcyjności przestrzeni miejskiej } \\
\hline & 3.2.1. Kompleksowe przedsięwzięcia rewitalizacyjne & 75862780 & 53201974 \\
\hline & 3.2.2. Inwestycje zwiększające potencjał rozwojowy miast & 75862780 & 53005918 \\
\hline \multirow{4}{*}{ śląskie } & \multicolumn{3}{|l|}{ Priorytet VI - Zrównoważony rozwój miast } \\
\hline & \multicolumn{3}{|l|}{ 6.2. Rewitalizacja obszarów zdegradowanych } \\
\hline & 6.2.1. Rewitalizacja - „duże miasta” & 87547596 & 68470000 \\
\hline & 6.2.2. Rewitalizacja - „małe miasta” & 86690916 & 67800000 \\
\hline \multirow{3}{*}{ świętokrzyskie } & \multicolumn{3}{|c|}{ Priorytet VI - Wzmocnienie ośrodków miejskich i rewitalizacja małych miast } \\
\hline & $\begin{array}{l}\text { 6.1. Wzmocnienie regionalnych i sub-regionalnych ośrodków } \\
\text { wzrostu }\end{array}$ & 55502908 & 47177472 \\
\hline & 6.2. Rewitalizacja małych miast & 32170803 & 27345182 \\
\hline \multirow{6}{*}{$\begin{array}{l}\text { warmińsko- } \\
\text {-mazurskie }\end{array}$} & \multicolumn{3}{|l|}{ Priorytet IV - Rozwój, restrukturyzacja i rewitalizacja miast } \\
\hline & \multicolumn{3}{|l|}{ 4.1. Humanizacja blokowisk } \\
\hline & $\begin{array}{l}\text { 4.1.1. Poprawa warunków technicznych budynków } \\
\text { zrealizowanych w technologii wielkiej płyty }\end{array}$ & 26218389 & 22285654 \\
\hline & 4.1.2. Wzmocnienie funkcji społecznych & 1176470 & 1000000 \\
\hline & 4.2. Rewitalizacja miast & 75528346 & $\begin{array}{r}41510743 \\
(\mathrm{~A}) \\
8054592 \\
(\mathrm{~B})\end{array}$ \\
\hline & 4.3. Restrukturyzacja terenów poprzemysłowych i powojskowych & 15464406 & 10072373 \\
\hline \multirow{3}{*}{ wielkopolskie } & \multicolumn{3}{|l|}{ Priorytet IV - Rewitalizacja obszarów problemowych } \\
\hline & 4.1. Rewitalizacja obszarów miejskich & 54500376 & 40875328 \\
\hline & $\begin{array}{l}\text { 4.2. Rewitalizacja zdegradowanych obszarów poprzemysłowych } \\
\text { i powojskowych }\end{array}$ & 21614325 & 13185824 \\
\hline \multirow{8}{*}{$\begin{array}{l}\text { zachodnio- } \\
\text { pomorskie }\end{array}$} & \multicolumn{3}{|l|}{ Priorytet V - Turystyka, kultura, rewitalizacja } \\
\hline & \multicolumn{3}{|l|}{ 5.5. Rewitalizacja } \\
\hline & 5.5.1. Rewitalizacja obszarów zdegradowanych & 26226860 & 11146416 \\
\hline & 5.5.2. Inicjatywa JESSICA & 14861887 & 11146416 \\
\hline & \multicolumn{3}{|l|}{ Priorytet VI - Rozwój funkcji metropolitalnych } \\
\hline & \multicolumn{3}{|l|}{ 6.6. Rewitalizacja na obszarze metropolitalnym } \\
\hline & $\begin{array}{l}\text { 6.6.1. Rewitalizacja obszarów zdegradowanych na obszarze } \\
\text { metropolitalnym }\end{array}$ & 32154664 & 13665732 \\
\hline & 6.6.2. Inicjatywa JESSICA na obszarze metropolitalnym & 18220976 & 13665732 \\
\hline
\end{tabular}


Każde z województw w ramach opracowanego Regionalnego Programu Operacyjnego wyróżniło priorytety i działania związane ściśle z rewitalizacją. Najwięcej środków pieniężnych na odnowę tkanki miejskiej zarezerwowano w województwie śląskim (136 mln euro), dolnośląskim (107 mln euro) i pomorskim (106 mln euro) (tab. 1, ryc. 5). Najtrudniej mówić o funduszach na odnowę tkanki miejskiej w województwie podlaskim, gdzie nie wyróżniono działania związanego wyłącznie z takimi projektami. Rewitalizacja ma być realizowana jako jedna z wielu możliwości w ramach Działania 1.1 - Tworzenie warunków dla rozwoju innowacyjności.

Ryc. 5. Wkład środków unijnych w programy rewitalizacji w ramach RPO

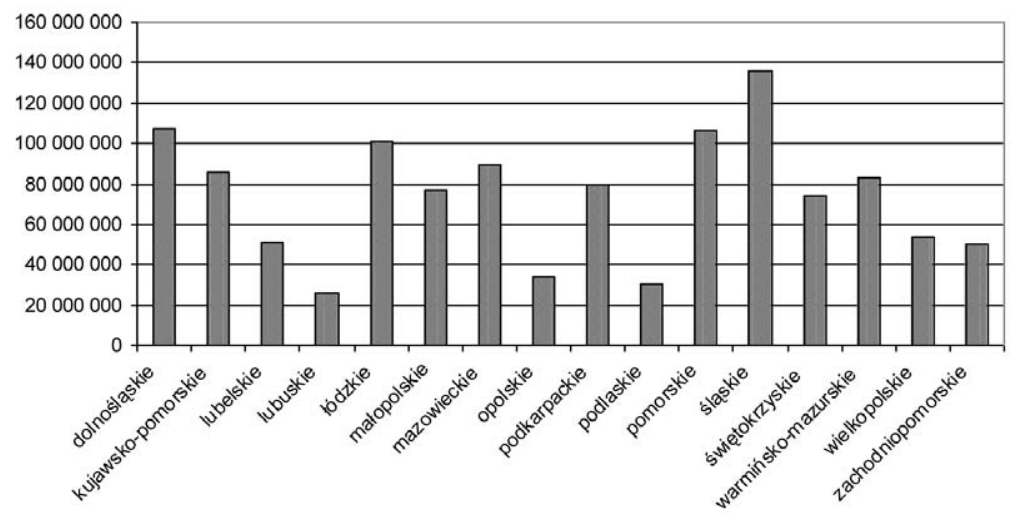

Źródło: opracowanie własne na podstawie tab. 1.

Podobnie jak w ZPORR, tak i w RPO można wyróżnić podstawowe kierunki działań rewitalizacyjnych:

1. Rewitalizacja obszarów poprzemysłowych i powojskowych - nawiązująca bezpośrednio do Działania 3.3.2 ZPORR. Takie typy projektów mają na celu zmianę dotychczasowych funkcji i adaptację budynków oraz obszarów pod nowe cele.

2. Rewitalizacja miast - rewaloryzacja osiedli mieszkaniowych, poprawa stanu technicznego budynków, a w szczególności tych wybudowanych z wielkiej płyty.

3. Rewitalizacja miast w kontekście społecznym. Można tutaj wyróżnić działania odnoszące się do humanizacji blokowisk, zwiększenia bezpieczeństwa, walki z patologiami oraz aktywizacją społeczności zamieszkującej tereny zdegradowane.

4. Rewitalizacja obszarów zdegradowanych, mająca na celu ożywienie gospodarcze dzięki wypromowaniu obszarów i obiektów rewitalizowanych.

W województwie małopolskim w ramach Działania $3.3 \mathrm{w}$ pierwszym naborze złożono 5 wniosków na łączną wartość 63,9 mln zł, przy oczekiwanym dofinansowaniu 47,9 mln zł, co przekroczyło znacznie fundusze EFRR na ten cel, które wynosiły 22,7 mln zł (ryc. 6, tab. 2). Jednak po każdym kolejnym etapie oceny, liczba wniosków ulegała redukcji przy jednoczesnym zmniejszeniu ogólnej wartości wsparcia. Tak po ocenie formalnej przyjęto wnioski, których dofinansowanie wyniosło $47,9 \mathrm{mln}$ zł, a po etapie oceny panelu ekspertów - już 11,5 mln zł. Regionalny Komitet Sterujący (RKS) i Zarząd Województwa Małopolskiego (ZWM) ostatecznie przyjęli do realizacji jeden wniosek o wartości 8,6 mln zł, z czego dofinansowanie z EFRR wyniosło maksymalną wartość 75\%, czyli 6,5 mln zł (ryc. 6, tab. 2). Nie wyczerpało to jednak całej kwoty przeznaczonej na dotacje projektów. 
Ryc. 6. Wartość oczekiwanego dofinansowania z EFRR w mln zł po kolejnych etapach selekcji w odniesieniu do kwoty alokacji w województwie małopolskim w latach 2004-2006

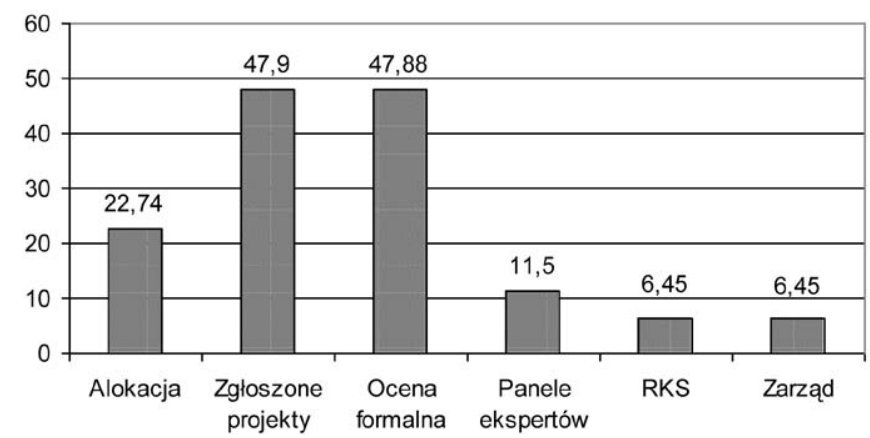

Źródło: opracowanie własne na podstawie Raportu z pierwszego naboru wniosków w ramach ZPORR 2004-2006 w województwie małopolskim.

Tab. 2. Zmiana liczby wniosków przy pierwszym naborze po poszczególnych etapach oceny w województwie małopolskim w okresie programowania 2004-2006

\begin{tabular}{|c|c|}
\hline \multicolumn{2}{|c|}{ Sytuacja po poszczególnych etapach oceny } \\
\hline Liczba zgłoszonych projektów & 5 \\
\hline Ocena formalna & 4 \\
\hline Panele ekspertów & 2 \\
\hline RKS & 1 \\
\hline Zarząd & 1 \\
\hline
\end{tabular}

Źródło: opracowanie własne na podstawie Raportu z pierwszego naboru wniosków w ramach ZPORR 2004-2006 w województwie małopolskim.

Ryc. 7. Wartość oczekiwanego dofinansowania z EFRR w mln zł po kolejnych etapach selekcji w odniesieniu do kwoty alokacji w województwie małopolskim w latach 2004-2006

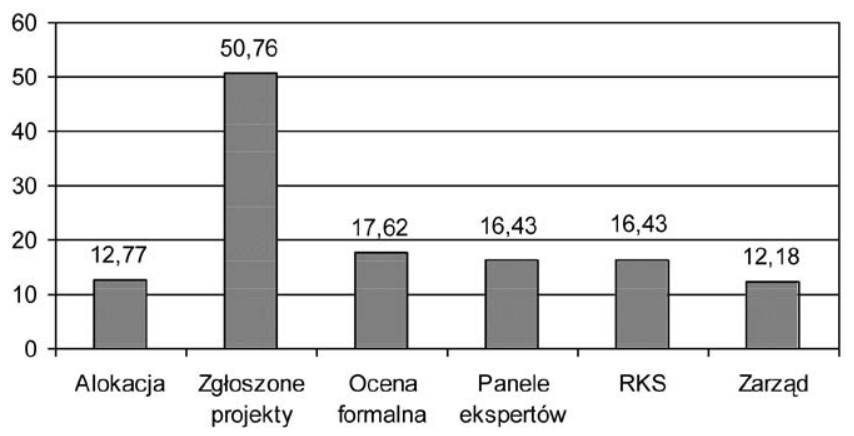

Źródło: opracowanie własne na podstawie Raportu z drugiego naboru wniosków w ramach ZPORR 2004-2006 w województwie małopolskim.

W drugim naborze zgłoszono 30 projektów na łączną kwotę 87,20 mln zł, przy oczekiwanym dofinansowaniu w ramach ZPORR 50,76 mln zł, co przekroczyło znacznie fundusze EFRR na ten cel, które wynosiły 12,18 mln zł (ryc. 7, tab. 3). Każdy kolejny etap, podobnie 
jak w pierwszym naborze, redukował liczbę przedsięwzięć. Do oceny formalnej przeszło 13 wniosków, których oczekiwane dofinansowanie wyniosło $17,62 \mathrm{mln}$ zł, a po etapie oceny panelu ekspertów i Regionalnego Komitetu Sterującego - 16,43 mln zł. Zarząd Województwa Małopolskiego ostatecznie przyjął do realizacji 9 wniosków o łącznej wartości $20,7 \mathrm{mln}$ zł, z czego dofinansowanie z EFRR wyniosło średnio 58\%, czyli $12 \mathrm{mln}$ zł (ryc. 7, tab. 3). Po raz pierwszy kwota przeznaczona na dotacje projektów została wykorzystana w $100 \%$.

Tab. 3. Zmiana liczby wniosków przy drugim naborze po poszczególnych etapach oceny w województwie małopolskim w okresie programowania 2004-2006

\begin{tabular}{|c|c|}
\hline \multicolumn{2}{|c|}{ Sytuacja po poszczególnych etapach oceny } \\
\hline Liczba zgłoszonych projektów & 30 \\
\hline Ocena formalna & 13 \\
\hline Panele ekspertów & 11 \\
\hline RKS & 11 \\
\hline Zarząd & 9 \\
\hline
\end{tabular}

Źródło: opracowanie własne na podstawie Raportu z drugiego naboru wniosków w ramach ZPORR 2004-2006 w województwie małopolskim.

W województwie małopolskim w ramach Działania $6.1 \mathrm{w}$ pierwszym naborze złożono 201 projektów na łączną wartość $1 \mathrm{mld} 65 \mathrm{mln}$ zł, przy oczekiwanym dofinansowaniu $1 \mathrm{mld}$ zł, co przekroczyło znacznie fundusze EFRR na ten cel, które wynosiły $249 \mathrm{mln}$ zł (ryc. 8). Po preselekcji wartość projektów wyniosła $1 \mathrm{mld} 406 \mathrm{mln}$, a spodziewane dofinansowanie 829,2 mln zł. Przedostatni etap selekcji wyłonił 44 wnioski na łączną kwotę 463,3 mln zł (przy dotacji 269,1 mln zł). Ostatecznie Zarząd Województwa zwrócił uwagę na niewystarczającą alokację środków, podejmując decyzję o ich zwiększeniu o 23,5 tys. euro. W ten sposób po ocenie strategicznej przyjęto 50 wniosków na łączną kwotę 513 mln zł, przy spodziewanym wsparciu 349 mln zł. Drugi konkurs planowany jest na III/IV kwartał 2010 roku.

Ryc. 8. Wartość oczekiwanego dofinansowania z EFRR w mln zł po kolejnych etapach selekcji w odniesieniu do kwoty alokacji w województwie małopolskim w latach 2007-2013

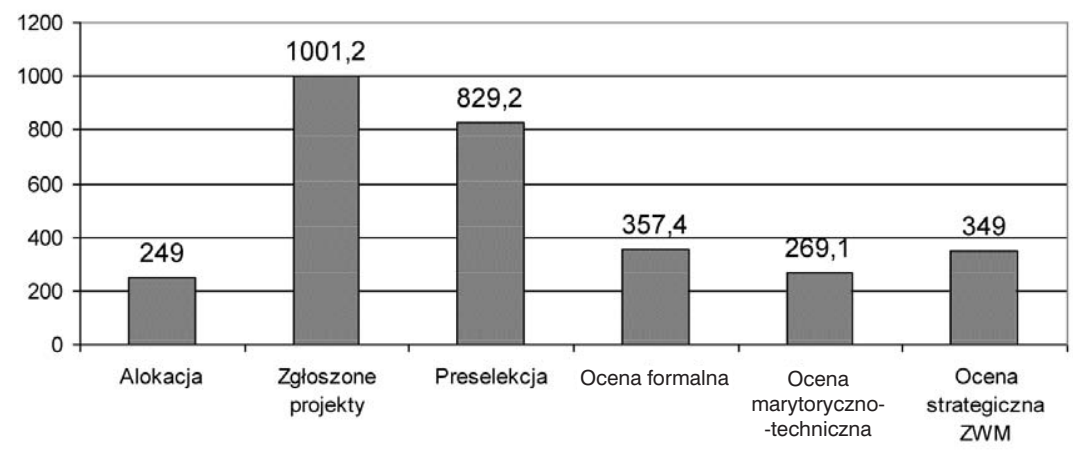

Źródło: opracowanie własne na podstawie http://www.wrotamalopolski.pl

W województwie świętokrzyskim na Działanie 3.3 przeznaczono 10,3 mln euro i w ramach tej kwoty zrealizowano jeden projekt (z dwóch zgłoszonych) - rewitalizacja śródmieścia 
Kielc, przebudowa ul. Sienkiewicza do ul. Żelaznej oraz do Pl. Moniuszki - o wartości 15,3 mln euro, przy wkładzie Unii $11 \mathrm{mln}$.

W odpowiedzi na konkurs ogłoszony w ramach Działania 6.1 (Wzmocnienie regionalnych i subregionalnych ośrodków wzrostu) oraz Działania 6.2 (Rewitalizacja małych miast) wpłynęło 49 wniosków o wartości całkowitej ok. 216,1 mln zł, w tym wartość dofinansowania z EFRR na ponad 126,3 mln zł. Na działanie 6.1 wpłynęło 10 wniosków o wartości całkowitej 80,1 mln zł (wartość dofinansowania z EFRR na ponad 42,8 mln zł), a na działanie 6.2 - 39 wniosków o wartości całkowitej $136 \mathrm{mln}$ zł (wartość dofinansowania z EFRR to ponad 83,5 $\mathrm{mln}$ zł). Ocenę formalną przeszło 48 wniosków, w tym 10 wniosków z Działania 6.1. Wartość całkowita inwestycji opiewa na kwotę ponad 215,8 mln zł, w tym dofinansowania z EFRR na ponad 123,7 mln zł (ryc. 9).

Ryc. 9. Wartość oczekiwanego dofinansowania z EFRR w mln zł po kolejnych etapach selekcji w odniesieniu do kwoty alokacji w województwie świętokrzyskim w latach 2007-2013

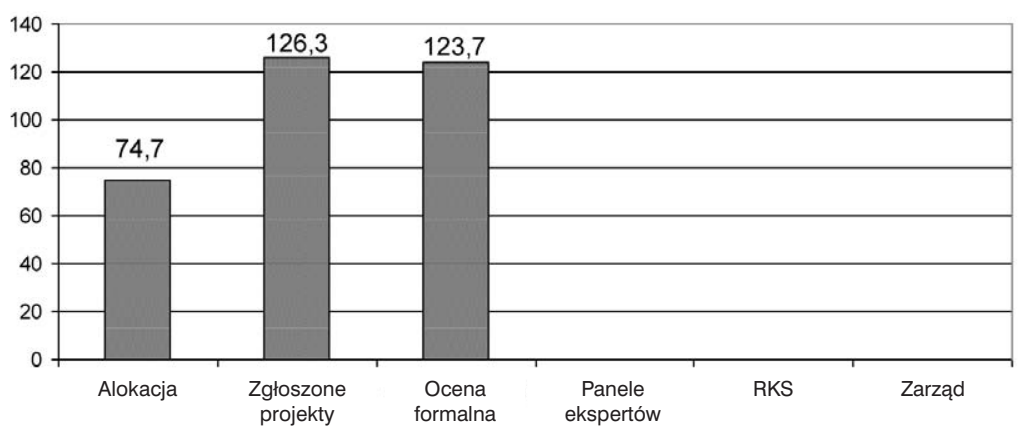

Źródło: opracowanie własne na podstawie http://www.rpo-świętokrzyskie.pl

Działania w ramach ZPORR były tylko programami pilotażowym przygotowującymi gminy do skorzystania z możliwości pokaźnych dofinansowań z Europejskiego Funduszu Rozwoju Regionalnego, dlatego z optymizmem należy patrzeć na wyniki wykorzystanych dofinansowań po drugim naborze, gdzie w każdym działaniu stopień zakontraktowanych środków wyniósł $100 \%$. Lepszy dostęp do informacji na temat pozyskiwania funduszy oraz nabyte doświadczenie po programie pilotażowym ZPORR szybko przyniosły pozytywne wyniki. Choć nie można mówić o wielkim sukcesie programów rewitalizacji w województwie małopolskim i świętokrzyskim w okresie 2004-2006, których ogólna wartość (41 mln zł) była na samym końcu w porównaniu z innymi działaniami, to jednak zainteresowanie tym zagadnieniem w nowym okresie programowania wyraźnie wzrosło. Już po pierwszym naborze wpłynęło 55 projektów w województwie małopolskim i 45 w województwie świętokrzyskim.

Pozostaje mieć nadzieję, że wyraźne kroki ze strony rządu, odzwierciedlające się w formie nowych ustaw i projektów dotyczących rewitalizacji, zainteresują tym zagadnieniem coraz to szerszą grupę beneficjentów, a przypadki gmin nie posiadających Lokalnych Programów Rewitalizacji będą nieliczne i nie będzie to stanowiło bariery uniemożliwiającej skorzystanie z dotacji Unii Europejskiej. Coraz sprawniejsze działanie urzędów, upraszczanie formularzy i procedur na pewno nie pozostaną niezauważone w nowym okresie programowania, a coraz większe kwoty do wykorzystania przyczynią się do zwiększenia konkurencyjności polskich województw nie tylko na arenie krajowej, ale także europejskiej i światowej. 


\section{Literatura}

1. Borowiec M., 2005, Rola praktyk z przedsiębiorczości w kształceniu studentów geografii na specjalności „przedsiębiorczość z gospodarkq przestrzenna” [w:] Przedsiębiorczość a współczesne wyzwania cywilizacyjne, red. Z. Zioło, T. Rachwał, „Przedsiębiorczość - Edukacja”, nr 1, Zakład Przedsiębiorczości i Gospodarki Przestrzennej Instytutu Geografii Akademii Pedagogicznej w Krakowie, Wydawnictwo „MiWa”, Kraków.

2. Gasidło K., Mazur K., Opania S., Pancewicz A., 2005, Stymulujaca rola funduszy europejskich w programach rewitalizacji obszarów miejskich. Obserwacje z praktyki [w:] „Czasopismo Techniczne. Architektura", Wyd. Politechniki Krakowskiej, Kraków.

3. Kaczmarek S., 2001, Rewitalizacja terenów poprzemysłowych. Nowy wymiar w rozwoju miast, Łódź.

4. Lorens P., 2005, Planowanie procesów rewitalizacji - od planowania przestrzennego do zarzqdzania strategicznego. Doświadczenie gdańskie [w:] „Czasopismo Techniczne. Architektura”, Wyd. Politechniki Krakowskiej, Kraków.

5. Markowski T., 1999, Zarzqdzanie rozwojem miast, PWN, Warszawa.

6. Rachwał T., 2005, Podstawy przedsiębiorczości - słownik dla liceum ogólnokształcacego, liceum profilowanego i technikum, wydawnictwo Nowa Era, Warszawa.

7. Raport z pierwszego naboru wniosków w ramach ZPORR 2004-2006 w Województwie Małopolskim, Departament Funduszy Strukturalnych Urzędu Marszałkowskiego Województwa Małopolskiego, Kraków.

8. Raport z drugiego naboru wniosków w ramach ZPORR 2004-2006 w Województwie Małopolskim, Departament Funduszy Strukturalnych Urzędu Marszałkowskiego Województwa Małopolskiego, Kraków.

9. Regionalne Programy Operacyjne na lata 2007-2013, Urzędy Marszałkowskie.

10. Skalski K., 2002, Rewitalizacja obszarów starej zabudowy w miastach, KIN, Kraków.

11. Uzupetnienie Zintegrowanego Programu Operacyjnego Rozwoju Regionalnego, Ministerstwo Rozwoju Regionalnego, Departament Wdrażania Programów Rozwoju Regionalnego.

12. Uszczegółowienia Regionalnych Programów Operacyjnych, 2009, Urzędy Marszałkowskie.

13. ZPORRe zmiany w regionach, 2008, Ministerstwo Rozwoju Regionalnego, Warszawa.

14. http://www.wrotamalopolski.pl

15. http://www.rpo-świętokrzyskie.pl 


\section{Revitalization Programs in the Integrated Operational Program of Regional Development and Regional Operational Programs}

Entrepreneurshi in european integration conditions is one of the key success factors in a context of individuals, companies or cities and local government units or states alike. In case of individuals entersprise attitude is recognized as a set of personal features. In case of cities it can be measured by sufficiency in gaining European funds and ability to apply them. In the times of globalisation and strong competition between cities ability to efficient management can decide in ,the chase for space”. This is even more important since cities play nowadays the basic part in social-economic growth processes and, in consequence, in increasing competitiveness of various types of spatial systems. As a result of numerous functional-spatial changes a lot of city areas have been devastated and other city parts gained a new rank. However, to create harmonious city space starting ventures which restore spatial order and meaning of marginalized areas turned out to be necessary. The rule of maximization of cities value and their real estate by creating high quality of public space is nowadays realized among the others by revitalization programs.

The aim of this essay is to indicate the revitalization activities in framework of Integrated Operational Program of Regional Development and Regional Operational Programs, comparison of means dedicated on revitalization and analysis of their application in małopolskie and świętokrzyskie woyevodship in which the results of application contest have been already publicated. 